\title{
MK-801 PRETREATMENT ENHANCES $N$-METHYL-D-ASPARTATE-MEDIATED BRAIN INJURY AND INCREASES BRAIN $N$-METHYL-D-ASPARTATE RECOGNITION SITE BINDING IN RATS
}

\author{
J. W. MCDonald, ${ }^{*}$ F. S. Silverstein $\dagger$ and M. V. Johnston $\ddagger \S$ \\ *Neuroscience and Medical Scientists Training Program, †Departments of Pediatrics and Neurology, \\ University of Michigan, Ann Arbor, MI, U.S.A. \\ $\ddagger$ Departments of Pediatrics and Neurology, The Kennedy Institute, Johns Hopkins University
} School of Medicine, Baltimore, MD, U.S.A.

\begin{abstract}
Direct intracerebral administration of $N$-methyl-D-aspartate typically produces focal brain injury. (+)-5-Methyl-10,11-dihydro-5H-dibenzo[a,d]cyclohepten-5,10-immine maleate (MK-801), a noncompetitive $N$-methyl-D-aspartate antagonist, can protect against $N$-methyl-D-aspartate-mediated brain injury when administered shortly before or after an intracerebral injection of $N$-methyl-D-aspartate. However, in this study we report that in perinatal rats if $\mathbf{M K - 8 0 1}(1 \mathrm{mg} / \mathrm{kg})$ is administered intraperitoneally 24 h prior to a unilateral intrastriatal $N$-methyl-D-aspartate injection, $N$-methyl-D-aspartatemediated brain injury is paradoxically enhanced. The severity of resulting brain injury is $15-25 \%$ greater in groups that received MK-801 in comparison with saline-treated controls $(P<0.001$, linear regression analysis). In contrast, the severity of brain injury resulting from intrastriatal injection of the glutamate agonist quisqualate is not altered by a similar $24 \mathrm{~h} \mathrm{MK}-801$ pretreatment. Furthermore, the enhanced toxicity of $N$-methyl-D-aspartate produced by a $24 \mathrm{~h}$ pretreatment with $\mathrm{MK}-801$ is completely blocked if a second dose of MK-801 is administered $15 \mathrm{~min}$ after the intrastriatal injection of $N$-methyl-Daspartate. To determine if MK-801 produced alterations in glutamate receptor pharmacology co-incident with the enhanced toxicity of $N$-methyl-D-aspartate, in vitro quantitative autoradiography for excitory amino acid receptor subtypes was performed with $\left[{ }^{3} \mathrm{H}\right]$ glutamate and $\left[{ }^{3} \mathrm{H}\right] N-1-(2$-thienyl)cyclohexyl-3,4piperidine in seven-day-old rats killed 2 or $24 \mathrm{~h}$ after MK-801 $(1 \mathrm{mg} / \mathrm{kg})$ administration. A $2 \mathrm{~h} \mathrm{MK-801}$ pretreatment produced a $30-50 \%$ increase in $\left[{ }^{3} \mathrm{H}\right]$ glutamate binding at $N$-methyl-D-aspartate preferring recognition sites in all four brain regions examined (areas CAI and CA3 of the hippocampus, corpus striatum, cingulate cortex $)$ in comparison with saline-treated controls $\left(P<0.05\right.$, ANOVA). $\left.{ }^{3} \mathrm{H}\right] \mathrm{N}-1-(2-$ Thienyl)cyclohexyl-3,4-piperidine binding to the phencyclidine site associated with the $N$-methyl-Daspartate receptor was reduced by $60-80 \%$ in all brain regions examined $(P<0.001)$. Quisqualate-sensitive $\left[{ }^{3} \mathrm{H}\right] \mathrm{glutamate}$ binding was not altered by a $2 \mathrm{~h}$ MK-801 pretreatment. In animals that received a $24 \mathrm{~h}$ MK-801 pretreatment, $N$-methyl-D-aspartate-sensitive [ ${ }^{3} \mathrm{H}$ ]glutamate binding remained elevated $(29 \%$ increase in $\mathrm{CAl}$ and $\mathrm{CA3}, P<0,05),\left[{ }^{3} \mathrm{H}\right] \mathrm{N}-1$ - (2-thienyl)cyclohexyl-3,4piperidine binding was still suppressed $(40 \%$ reduction in $\mathrm{CAl}$ and $\mathrm{CA} 3, P<0.05)$ and quisqualatesensitive $\left[{ }^{3} \mathrm{H}\right]$ glutamate binding was reduced by $15-20 \%$ in area $\mathrm{CA} 3$ and in the corpus striatum $(P<0.05$, ANOVA).

The results suggest that MK-801 induces rapid and persistent up-regulation of $N$-methyl-D-aspartate receptors and sensitizes the brain to $N$-methyl-D-aspartate-induced injury as the level of MK-801 in the brain declines. The observations provide new information about regulation of the $N$-methyl-D-aspartate receptor complex and may be relevant in the analysis of the neuroprotective properties of phencyclidine receptor ligands.
\end{abstract}

Intrastriatal injection of $N$-methyl-D-aspartate (NMDA), an analog of the excitatory neurotransmitter glutamate, typically produces focal brain injury in rodents. ${ }^{4.10 .18 .20 .216 .35}$ The neurotoxicity appears to be mediated by the NMDA receptor-channel complex and is prevented by specific antagonists selective for this site..$^{5,11.17 .20 .21}$ Study of this model of neurotoxicity may be relevant to development of novel therapeutic strategies for several neurological dis-

$\S$ To whom correspondence should be addressed.

Abbreviations: EAA, excitatory amino acid; MK-801, $(+)$ 5-methy]-10,11-dihydro-5H-dibenzo[ $a, d]$ cyclohepten-5, 10-imine maleate: NMDA, $N$-methyl-D-aspartate; PCP, phencyclidine; PND, postnatal day; TCP, $N \cdot 1 \cdot(2-$ thienyl)cyclohexyl-3,4-piperidine. orders. Experimental evidence has linked overactivation of NMDA receptors to the pathophysiology of neuronal degeneration from hypoxia-ischemia, status epilepticus and other chronic neurologic

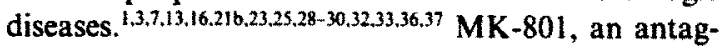
onist of NMDA receptors which binds to the phencyclidine (PCP) site associated with the NMDA channel, is among the most neuroprotective compounds against NMDA toxicity..$^{17.20}$ In order to further characterize the pharmacologic characteristics of MK-801 treatment in vivo, this study examines the effects of MK-801 pretreatment on NMDA-induced brain injury and on binding to excitatory amino acid receptors. A preliminary report of this work has been presented. ${ }^{19}$ 


\section{EXPERIMENTAL, PROCEDURES}

\section{Experimental protocols}

To determine the effect of $24 \mathrm{~h} \mathrm{MK}-801$ pretreatment on NMDA-mediated brain injury, postnatal day (PND) 6 rats (Sprague-Dawley, Charles River) were administered $1 \mathrm{mg}$ $\mathrm{kg}$ (in $0.05 \mathrm{ml}$ phosphate-buffered saline) MK-801 i.p. or an equivalent volume saline. Twenty-four hours later amounts of NMDA varying from 5 to $25 \mathrm{nmol}$ were injected into the right striatum. Animals were killed on PND I2. The number of animals used per group ( $n=$ saline-treated, MK-801treated) were: 5 nmol NMDA $(n=9,8) ; 10$ nmol NMDA $(n-16,16) ; 17 \mathrm{nmol}$ NMDA $(n=8,9), 25 \mathrm{nmol}$ NMDA $(n=20,17)$. Experiments were performed with PND 6-7 age animals because this represents an important developmental time point with regard to the ontogeny of excitatory amino acid (EAA) receptors and EAA neurotoxicity. ${ }^{18}$

To examine, in greater detail, the effect of the time interval between MK-801 pretreatment and intrastriatal injection of NMDA on the severity of NMDA-induced brain injury, PND 7 rats were administered $1 \mathrm{mg} / \mathrm{kg} \mathrm{MK}$ 801 at five time intervals before unilateral intrastriatal injection of $25 \mathrm{nmol}$ NMDA. Time intervals (in hours) were: $0.5 .2,6,12,24$ ( $n=7 /$ group); NMDA-injected controls received saline $(n=13)$. Animals were killed on PND 12 . The extent of damage produced by NMDA in saline-treated animals at these time intervals did not differ among groups and all saline-treated, NMDA-injected controls were pooled for statistical analysis ( $P=$ non-significant, one-way ANOVA).

To determine whether the enhanced toxicity of NMDA produced by MK- 801 pretreatment could be blocked by an NMDA antagonist, two groups of PND 6 rats received either $1 \mathrm{mg} / \mathrm{kg} \mathrm{MK}-801(n=9)$ or saline $(n=11)$ and $24 \mathrm{~h}$ later pups in both groups were injected intrastriatally with $25 \mathrm{nmol}$ NMDA. Fifteen minutes later all animals received a second injection of MK-801 (1 mg/kg). Animals were decapitated on PND 12.

To determine if the enhanced toxicity of NMDA produced by $24 \mathrm{~h}$ MK-801 pretreatment was the result of adverse systemic effects such as hypotension, respiratory depression, decreased food intake or prolonged sedation, chloral hydrate was used to produce a similar depth and duration of anesthesia as $1 \mathrm{mg} / \mathrm{kg} \mathrm{MK}-801$. PND 6 rats received two i.p. injections of either chloral hydrate $(100 \mathrm{mg} / \mathrm{kg}$ each: $n=6)$ or saline $(n=8)$. Twenty-four hours later $17 \mathrm{nmol}$ of NMDA was injected into the right striatum.

To determine if the ability of $\mathrm{MK}-801$ to enhance brain injury was selective for NMDA-induced damage. intrastriatal injections of the neurotoxic glutamate agonist quisqualate were carricd out in rats that received MK-801 $24 \mathrm{~h}$ earlier. PND 6 rats received $1 \mathrm{mg} / \mathrm{kg} \mathrm{MK}-801(n=10)$ or saline $(n=10)$. Twenty-four hours later. $100 \mathrm{nmol}$ quisqualate was injected into the right striatum. Animals were decapitated on PND 12. Administration of larger doses of quisqualate $(>100 \mathrm{nmol})$ that produce a level of brain injury equivalent to intermediate doses of NMDA $(10-25 \mathrm{nmol})$ was limited by the solubility of quisqualate. the injection volume $(0.5 \mu 1)$, and seizure related increased mortality rate.

Quantitative receptor autoradiography was used to examine the hypothesis that MK-801-induced alterations in EAA receptor binding characteristics may be associated with the enhanced toxicity of NMDA produced by MK -801 pretreatment. PND $6(n=6)$ and PND $7(n=6)$ rats received either $1 \mathrm{mg} / \mathrm{kg} \mathrm{MK}-801 \quad(n=3 /$ age $)$ or saline $(n=3 /$ age $)$, i.p. Twenty-four or two hours later the rats were decapitated. Three receptor assays were used to assess NMDA. quisqualate and PCP selective receptors as described below. Scatchard analysis of NMDA receptor binding was carried out in an additional set of PND 6 rats treated with $1 \mathrm{mg} / \mathrm{kg}$ $(n=3)$ or saline $(n=3)$ and killed $2 \mathrm{~h}$ later

\section{Intracerebral injections}

Injections were performed as previously described Briefly, PND 7 rats were anesthetized with ether and a mid. line scalp incision was made to expose the calvarium. Pups were positioned in a plaster of Paris mold of the head and body. Intracerebral stereotaxic injections were performed with a 26-gauge, beveled tip. Hamilton syringe using a Kopf small animal apparatus. All intracerebral injections were made in the posterior striatum. Using bregma as a landmark. injection site coordinates were AP $2.0 \mathrm{~mm}, \mathrm{~L} 2.5 \mathrm{~mm}$ at a depth of $4 \mathrm{~mm}$ from the dura. The needle was left in place for 2 min following injection to limit leakage. NMDA and quisqualate were dissolved in $0.01 \mathrm{M}$ Tris buffer, pH 7.4. Pups received varying amounts of NMDA or quisqualate intrastriatally in a volume of $0.5 \mu \mathrm{l}$. The scalp was sutured with 6-0 nylon suture. Rats were subsequently placed under a warming lamp set to maintain a $37^{\circ} \mathrm{C}$ body temperature. for $2 \mathrm{~h}$. Pups were then returned to their mother, Five days later, on PND 12, animals were killed by decapitation

Quantification of brain injury by comparison of cerehral hemisphere n'eights

The forebrain was separated from the cerebellum and brainstem using a razor blade. The two cerebral hemispheres were separated and weighed. Hemisphere weight disparities were compared for each animal using the formula $100^{*}$ $(C-I) / C=$ per cent damage, a value that reflects the severity of damage of the injected $(I)$ cerebral hemisphere relative to the contralateral $(C)$ hemisphere. This is an accurate and sensitive method for quantification of brain injury in perinatal rats ${ }^{20-21 a}$ and the size of the contralateral hemisphere did not differ from controls. Values presented are mean \pm S.E.M

A second value, per cent protection was calculated to compare the severity of brain damage present in MK-801treated animals relative to saline-treated controls

per cent protection $=100^{*}$

$$
\times\left[1-\frac{(\text { per cent damage, } M K-801-\text { treated) }}{\text { (per cent damage, saline-treated) }}\right] \text {. }
$$

Data represent mean \pm S.E.M

\section{Autoradiograph1}

Brains were removed and rapidly frozen on dry ice Horizontal frozen brain sections were thaw-mounted onto gelatin-coated slides. ['H]Glutamate (Amersham) was used to label NMDA-sensitive and quiqualate-sensitive glutamate receptors, and [ $\left.{ }^{3} \mathrm{H}\right] \mathrm{N}-1$-(2-thienyl)cyclohexyl-3,4piperidine [ $\left.{ }^{3} \mathrm{H}\right]$ TCP (New England Nuclear) was used to label PCP receptors in adjacent sections from saline-and MK-801-treated animals as previously described. $2,8.9 .14 .26$

Briefly. sections were washed in cold buffer for $30 \mathrm{~min}$ and incubated for $45 \mathrm{~min}$ under one of the following buffer conditions: NMDA-sensitive glutamate binding, $40 \mathrm{nM}$ ['H]glutamate in $50 \mathrm{mM}$ Tris-acetate, pH 7.2, plus $2.5 \mu \mathrm{M}$ quisqualate to block binding to quisqualate receptors; 9.14 quisqualate-sensitive glutamate binding, $40 \mathrm{nM}$ [ [3]glutamate in $50 \mathrm{mM}$ Tris $-\mathrm{HCl}$, pH 7.4, containing $100 \mu \mathrm{M}$ NMDA and $2.5 \mathrm{mM} \mathrm{CaCl} ; 29$ TCP binding, $30 \mathrm{nM} \mathrm{[}{ }^{3} \mathrm{HTCP}$ in $50 \mathrm{mM}$ Tris-acetate, pH 7.4, plus $1 \mathrm{mM}$ magnesium acetate. ${ }^{14}$ Non-specific binding was determined in the presence of $1 \mathrm{mM}$ glutamate for [ $\left.{ }^{3} \mathrm{H}\right]$ glutamate binding assays or $20 \mu \mathrm{M}$ TCP binding. Rinses included: three quick squirts with $2 \mathrm{ml}$ ice-cold buffer followed by one final $2-\mathrm{ml}$ rinse with cold glutaraldehyde: acetone $(1: 19, v: v)$ mixture for $\left[{ }^{3} \mathrm{H}\right.$ ]glutamate assays; three 1 -min rinses with ice-cold buffer for TCP binding assays. Sections were rapidly dried under a stream of warm air.

The quisqualate-sensitive $\left[{ }^{3} \mathrm{H}\right]$ glutamate binding sites measured in this autoradiography assay likely represen postsynaptic neuronal non-NMDA receptors. In contrast to binding in membranes, quisqualate-sensitive [ ${ }^{3} \mathrm{H}$ ]glutamate binding in the presence of $\mathrm{CaCl}_{2}$ in tissue sections represents postsynaptic high affinity neuronal binding sites rather than 
sequestration sites. ${ }^{2}$ For saturation studies of NMDA receptor binding, sections were incubated for $45 \mathrm{~min}$ at $4^{\circ} \mathrm{C}$ in $50 \mathrm{mM}$ Tris-acetate containing $30 \mathrm{nM}\left[{ }^{3} \mathrm{H}\right]$ glutamate and varying concentrations of unlabeled $\mathrm{L}$-glutamate ranging from $10 \mathrm{nM}$ to $2 \mu \mathrm{M}$.

All sections were placed in X-ray cassettes with appropriate standards, apposed to ${ }^{3} \mathrm{H}$-sensitive Ultrafilm, exposed for three to six weeks, developed and analysed densitometrically using a microcomputer-based video densitometer system; ${ }^{926}$ (Imaging Research, St Catherines, Ontario). Ten readings were taken bilaterally and averaged for each of four brain regions examined; CAI and CA3 hippocampal subfields (stratum radiatum laminae), corpus striatum, and cingulate cortex.

Statistical analysis

A microcomputer-based software program (Systat) was used for statistical analysis. Linear regression analysis was used to test the effect of $24 \mathrm{~h}$ MK-801 pretreatment on the severity of NMDA-mediated brain injury; a simultaneous test of slope and intercept for differences between lines in the linear phase was used since a linear trend existed and data points were not independent. ANOVA was used to compare the effect of the time interval between MK-801 treatment and intrastriatal injection of NMDA on the severity of NMDA-mediated brain injury and was used to determine the effect of MK-801 pretreatment on NMDA, PCP and quisqualate receptor binding. All other tests were independent $t$-tests unless stated otherwise.

\section{A}
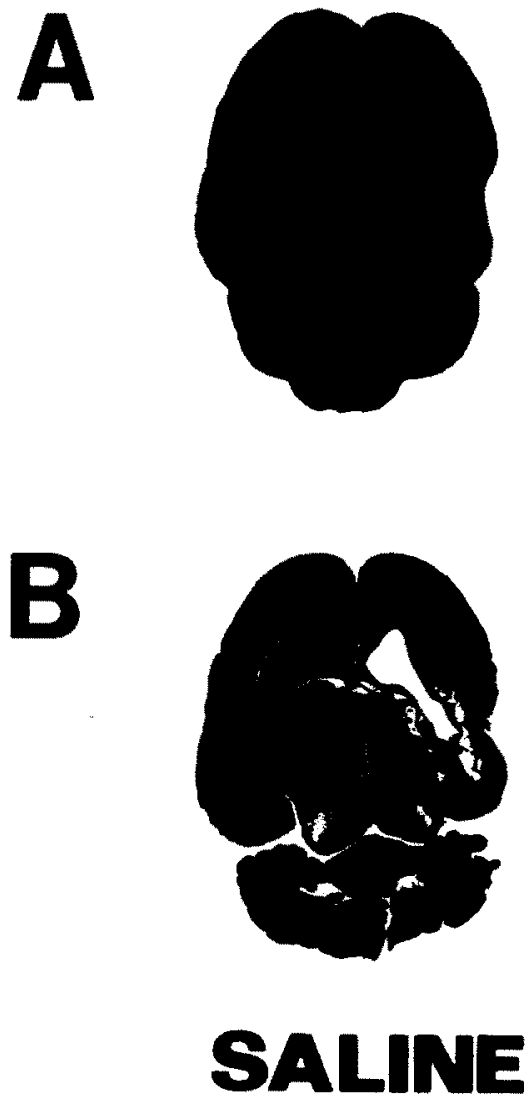

RESULTS

\section{Neurotoxicity}

In rats treated with MK-801 $24 \mathrm{~h}$ prior to NMDA injection, the size of the NMDA lesion was visibly larger than that produced by the same amount of NMDA in saline-treated rats (Fig. 1A). Comparison of Nissl-stained coronal brain sections from rats treated with either MK-801 or saline and injected with NMDA demonstrates similar results (Fig. 1B). Histograms comparing the severity of brain injury produced by unilateral intrastriatal injection of increasing amounts of NMDA $(5,10,17,25 \mathrm{nmol})$ in rats that received i.p. injections of either $1 \mathrm{mg} / \mathrm{kg}$ MK-801 or saline $24 \mathrm{~h}$ earlier are presented in Fig. 2. The severity of brain injury as assessed by disparities in cerebral hemisphere weights was greater in groups that received MK-801 $24 \mathrm{~h}$ earlier compared with saline-treated groups (regression analysis, $P<0.001$, simultaneous test for slope and intercept). The mortality rate in saline-treated animals was $0 \%$ in groups that received $17 \mathrm{nmol}$ of NMDA or less and was $5 \%$ in groups that received $25 \mathrm{nmol}$ NMDA. Mortality rates in groups that received MK-801 $24 \mathrm{~h}$ before
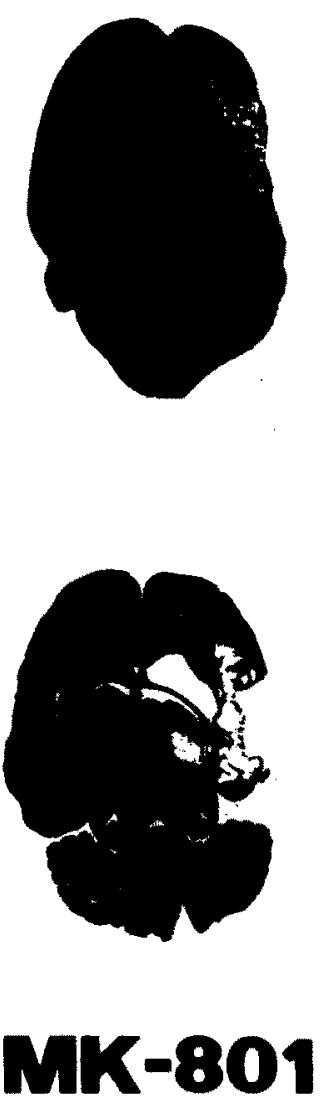

Fig. 1. Comparison of NMDA-induced brain injury in whole brains (A) and in corresponding Nissl-stained coronal brain sections (B) from rats that received either $1 \mathrm{mg} / \mathrm{kg} \mathrm{MK-801}$ or saline, i.p., $24 \mathrm{~h}$ before unilateral intrastriatal injection of $25 \mathrm{nmol}$ NMDA on PND 7, MK-801 and saline were administered on PND 6. Animals were killed five days after NMDA injection. The whole brain and tissue section on the right are representative of rats that received MK-801 whereas the ones on the left are representative of saline-treated animais. The increased severity of the NMDA-induced lesion is evident in brains from MK-801-treated rats in comparison with saline-treated controls. 


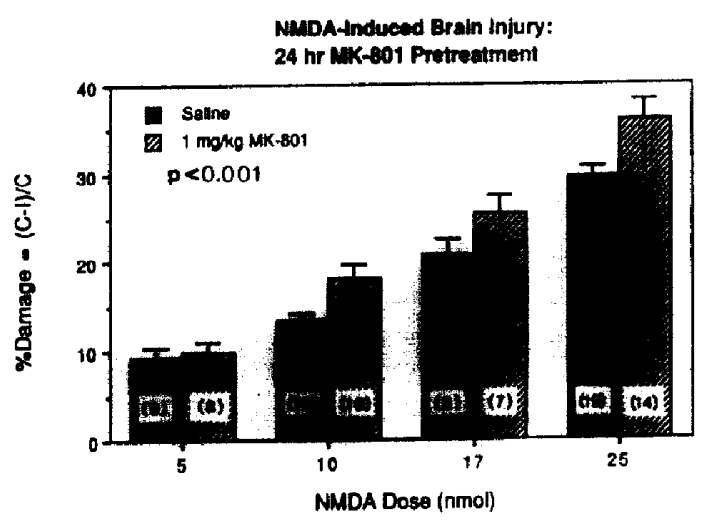

Fig. 2. Histograms comparing the severity of brain injury produced by unilateral intrastriatal injection of increasing amounts of NMDA in rats that received either $1 \mathrm{mg} / \mathrm{kg}$ MK-801 or saline $24 \mathrm{~h}$ earlier. PND 6 rats received i.p. injections of either MK-801 or saline. Twenty-four hours later NMDA was injected intrastriatally. After five days, the severity of brain injury was assessed by comparison of the weights of the injected and contralateral cerebral hemispheres. ${ }^{20.21 \mathrm{a}}$ Paradoxically, the degree of brain damage was significantly greater in groups that received MK-80I in comparison with groups that received saline (regression analysis $<0.001$, simultaneous test of slope and intercept for differences between lines in the linear phase). Values represent the mean \pm S.E.M. for the number of surviving animals indicated in parentheses.

NMDA were slightly greater: $18 \%, 12.5 \%$, and $0 \%$ in groups that received 25,17 , and 10 or less nmol of NMDA, respectively. Administration of MK-801 ( $1 \mathrm{mg} / \mathrm{kg}$ ) in the absence of NMDA produced no signs of neurotoxicity when assessed by light microscopy five days later $(n=5)$.

In contrast to the effect of $24 \mathrm{~h} \mathrm{MK}-801$ pretreatment on the severity of NMDA-induced brain damage, administration of MK-801 at intervals up to $12 \mathrm{~h}$ before intrastriatal injection of NMDA significantly reduced the degree of resulting brain injury, $P<0.001$, ANOVA, MK-801-treated vs salinetreated (Fig. 3). The degree of protection against NMDA toxicity produced by MK-801 was $98.9 \pm 2.8 \%$ in animals treated with MK-801 $0.5 \mathrm{~h}$ prior to injection of NMDA and declined to $72.5 \pm 2.6 \%, 65.1 \pm 6.4 \%$ and then $54.8 \pm 3.1 \%$ protection when the time interval was extended to 2,6 or $12 \mathrm{~h}$, respectively. Mortality rate in the saline-treated group was $15 \%$ and was $0 \%$ in animals treated with MK-801 0.5-12 h before injection of NMDA.

The enhanced toxicity of NMDA produced by $24 \mathrm{~h}$ MK-801 pretreatment was blocked by a second injection of MK-801 $15 \mathrm{~min}$ after intrastriatal injection of $25 \mathrm{nmol}$ NMDA (Table 1). The severity of brain injury expressed as per cent damage, mean \pm S.E.M., was $0.98 \pm 0.55 \%$ in salinepretreated animals that received $1 \mathrm{mg} / \mathrm{kg} \mathrm{MK}-801$ $15 \mathrm{~min}$ after the intrastriatal NMDA injection $(n=11)$ and $1.10 \pm 0.82 \%$ in MK-801-pretreated animals that received a second post-NMDA injection of MK- $801(n=9)$. There was no mortality in these two groups of animals.

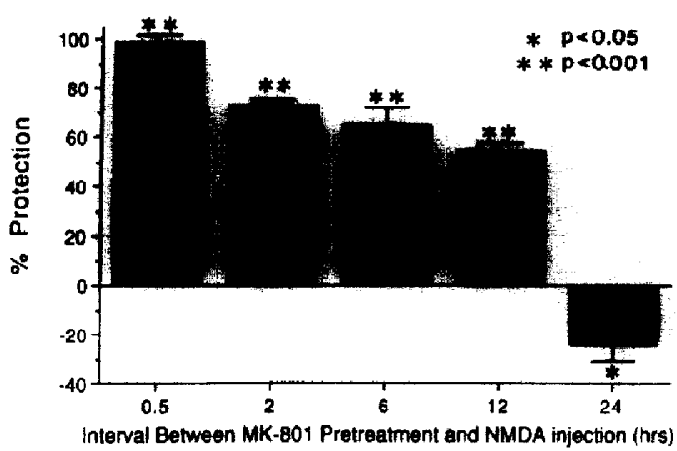

Fig. 3. Histograms comparing the effects of the time intervals between MK-801 pretreatment and intrastriatal injection of NMDA on the severity of NMDA-induced brain injury. NMDA (25 nmol in $0.5 \mu \mathrm{l}$ ) was injected unilaterally into the striatum of PND 7 rats. One milligram per kilogram MK-801 was administered intraperitoneally $0.5,2,6,12$ and $24 \mathrm{~h}$ prior to the intrastriatal injection of NMDA ( $n=6-7 /$ group). Eleven saline-treated, NMDA-injected animals served as controls. Animals were killed on PND 12 and the severity of brain injury was assessed by comparison of the weights of the injected and contralateral cerebral hemispheres. ${ }^{20}$ Data represent mean \pm S.E.M. and are expressed as per cent protection (\% Protection), which relates the degree of brain injury in MK-801-treated animals with that observed in saline-treated, NMDA-injected controls ( $31.8 \pm 0.9 \%$ damage, $n=11$ ). MK-801 produced significant levels of protection against NMDA toxicity when administered $0.5,2,6$, and $12 \mathrm{~h}$ prior to intrastriatal injection of NMDA in comparison with saline-treated. NMDAinjected controls $(P<0.001$ vs saline-treated. NMDAinjected controls, ANOVA). In contrast, adminjstration of MK-801 $24 \mathrm{~h}$ prior to intrastriatal injection of NMDA paradoxically enhanced the severity of NMDA-mediated brain injury $(P<0.05$ vs saline-treated, NMDA-injected controls, ANOVA).

The enhancement of NMDA-mediated neurotoxicity is probably not related to a non-specific effect of

Table 1. Effect of MK-801 treatment on $N$-methyl-D-aspartate-mediated brain injury

\begin{tabular}{|c|c|c|c|}
\hline \multicolumn{2}{|c|}{ Treatment } & \multirow{2}{*}{$\begin{array}{c}\text { Per cent } \\
\text { damage } \\
(\text { mean } \pm \text { S.E.M. })\end{array}$} & \multirow[b]{2}{*}{$n i$} \\
\hline PND $6 \dagger$ & PND $7 \ddagger$ & & \\
\hline Saline & NMDA & $29.55 \pm 1.24$ & 19 \\
\hline Saline & NMDA + MK - 801 & $0.98 \pm 0.55^{* *}$ & 11 \\
\hline MK-801 & NMDA & $36.96 \pm 2.21^{*}$ & 14 \\
\hline MK-801 & $\mathrm{NMDA}+\mathrm{MK}-801$ & $1.10 \pm 0.82^{* * *}$ & 9 \\
\hline
\end{tabular}

The enhanced toxicity of NMDA produced by MK-801 pretreatment was completely blocked by a second injection of MK-801 shortly after the intrastriatal injection of NMDA.

${ }^{*} P<0.01$ vs saline, NMDA treatment, independent $t$-tests. ** $P<0.001$ vs saline, NMDA treatment.

*** $P<0.001$ vs MK-801, NMDA treatment.

$\lceil\mathrm{MK}-801(1 \mathrm{mg} / \mathrm{kg})$ and saline were administered i.p. in $0.05 \mathrm{ml}$.

ఫNMDA (25 nmol/ $0.5 \mathrm{ml})$ was injected intrastriatally $24 \mathrm{~h}$ after PND 6 treatment. MK-80! $(1 \mathrm{mg} / \mathrm{kg})$ was administered i.p. $15 \mathrm{~min}$ after NMDA injections.

$\$ P e r$ cent damage refers to the decrease in the weight of the injected $(I)$ relative to the contralateral $(C)$ cerebral hemispheres using the equation:

$$
\text { per cent damage }=100^{*}(C-I) / C \text {. }
$$

in $n=$ number of surviving animals. 
Table 2. Effect of chloral hydrate-induced sedation on $N$-methyl-D-aspartate-mediated brain injury

\begin{tabular}{lccc}
\hline & Treatment & $\begin{array}{c}\text { Per cent } \\
\text { damage\$ }\end{array}$ & \\
PND 6 & PND 7 & $($ mean \pm S.E.M.) & $n \|$ \\
\hline Saline & NMDA & $16.22 \pm 2.51$ & 8 \\
$\begin{array}{c}\text { Chloral } \\
\text { hydrate }\end{array}$ & $\begin{array}{c}\text { NMDA } \\
\text { NMmol) }\end{array}$ & $15.85 \pm 2.91$ & 6 \\
\hline
\end{tabular}

Chloral hydrate at doses that reproduced the duration and depth of sedation produced by $1 \mathrm{mg} / \mathrm{kg}$ MK-801 did not alter NMDA toxicity when administered $24 \mathrm{~h}$ earlier.

†Chloral hydrate $(100 \mathrm{mg} / \mathrm{kg}$ per dose) and saline were administered i.p. in $0.05 \mathrm{ml}$.

$\ddagger$ NMDA (I $7 \mathrm{nmol} / 0.5 \mu \mathrm{l})$ was injected intrastriatally $24 \mathrm{~h}$ after PND 6 treatment.

\$Per cent damage refers to the decrease in the weight of the injected $(I)$ relative to the contralateral $(C)$ cerebral hemisphere using the equation:

$$
\text { per cent damage }=100^{*}(C-I) / C .
$$

$\| n=$ number of surviving animals.

prolonged sedation. The severity of NMDAmediated brain injury was not altered by pretreatment with chloral hydrate at doses that produced a similar depth and duration of sedation as that produced by $1 \mathrm{mg} / \mathrm{kg} \mathrm{MK}-801$ (Table 2). In animals that received two i.p. injections of chloral hydrate $(100 \mathrm{mg} / \mathrm{kg}$ each) the severity of brain damage produced by $17 \mathrm{nmol}$ NMDA was $15.85 \pm 2.91 \%(n=6)$ with a corresponding value of $16.22 \pm 2.51 \%$ in animals that received two i.p. injections of saline $(n=8)$. All animals survived.

The selectivity of the effect of $24 \mathrm{~h}$ MK- 801 pretreatment on NMDA specific damage was demonstrated by the observation that the severity of quisqualate-mediated brain injury was not altered by $24 \mathrm{~h}$ MK-801 pretreatment (Table 3). The severity of brain damage (per cent damage, mean \pm S.E.M.)

Table 3. Effect of $24 \mathrm{~h} \mathrm{MK-801} \mathrm{pretreatment} \mathrm{on} \mathrm{quis-}$ qualate-mediated brain injury

\begin{tabular}{|c|c|c|c|}
\hline \multicolumn{2}{|r|}{ Treatment } & \multirow{2}{*}{$\begin{array}{c}\text { Per cent } \\
\text { damage } \\
(\text { mean } \pm \text { S.E.M.) }\end{array}$} & \multirow[b]{2}{*}{$n \|$} \\
\hline PND $6 \dagger$ & PND $7 \ddagger$ & & \\
\hline Saline & $\begin{array}{l}\text { Quisqualate } \\
\text { (100 nmol) }\end{array}$ & $7.54 \pm 1.33$ & 10 \\
\hline MK-801 & $\begin{array}{l}\text { Quisqualate } \\
\text { (100 nmol) }\end{array}$ & $7.62 \pm 0.72$ & 9 \\
\hline
\end{tabular}

The ability of MK-801 to enhance the severity of NMDAmediated brain injury appears to be selective, since administration of MK-80I $24 \mathrm{~h}$ prior to intrastriatal injection of quisqualate did not alter the severity of resulting brain injury.

$\dagger \mathrm{MK}-80 \mathrm{l}(1 \mathrm{mg} / \mathrm{kg})$ and saline were administered i.p. in $0.05 \mathrm{ml}$.

†Quisqualate $(100 \mathrm{nmol} / 0.5 \mu \mathrm{l})$ was injected intrastriatally $24 \mathrm{~h}$ after PND 6 treatment.

$\S P e r$ cent damage refers to the decrease in the weight of the injected $(I)$ relative to the contralateral $(C)$ cerebral hemispheres using the formula:

$$
\text { per cent damage }=100^{*}(C-I) / C .
$$

$\| n=$ number of surviving animals. produced by intrastriatal injection of $100 \mathrm{nmol}$ quisqualate was $7.54 \pm 1.33 \%(n=9)$ in animals treated with saline and $7.62 \pm 0.72 \%(n=10)$ in animals treated with MK-801 $24 \mathrm{~h}$ prior to the injection of quisqualate. One out of 10 animals that received MK-801 $24 \mathrm{~h}$ prior to injection of quisqualate died whereas all animals survived in the saline-treated group. The use of quisqualate as a control to determine the selectivity of the effect of $24 \mathrm{~h}$ MK-801 treatment on neurotoxicity is limited due to the low solubility and toxicity of quisqualate at this age. For these reasons, doses of quisqualate that were equipotent with the doses of NMDA used could not be tested. Therefore, it is possible that toxicity resulting from equipotent doses of a quisqualate receptor agonist may be altered by $24 \mathrm{~h}$ MK-801 pretreatment as may be suggested by the reduction of quisqualate receptor binding produced by $24 \mathrm{~h}$ MK- 801 pretreatment (see below).

\section{Autoradiography}

In PND 7 rats treated with MK-801 (1 mg/kg) $2 \mathrm{~h}$ prior to being killed, NMDA-sensitive $\left[{ }^{3} \mathrm{H}\right]$ glutamate binding in the CAl stratum radiatum was increased by $41.5 \%$ above saline-treated controls (MK-801treated, $n=3,1479 \pm 73.8$ vs saline-treated, $n=3$, $1045.5 \pm 31.4 \mathrm{fmol} / \mathrm{mg}$ protein, $P<0.001$, paired $t$ test, see Fig. 4). In an additional group of PND 6 rats, saturation analysis indicated that the increase in NMDA receptor binding produced by $2 \mathrm{~h}$ MK-801 pretreatment was apparently the result of an increase in the number of binding sites rather than a change in affinity $\left[B_{\max }, \mathrm{pmol} / \mathrm{mg}\right.$ protein, MK-801-treated, $n=3, \quad 2.82 \pm 0.42 \quad$ vs saline-treated, $\quad n=3$, $1.58 \pm 0.25, p<0.05$, paired $t$-test; $K_{D}(\mathrm{nM})$, MK-801-treated, $147.61 \pm 15.81$ vs saline-treated, $108.80 \pm 46.72, P=$ non-significant]. The apparent discrepancy between the maximum number of NMDA binding sites determined directly by saturation analysis and by extrapolation from single concentration studies likely reflects the different age animals used in each study. The animals were six days old in saturation studies and seven days old in single concentration studies. Due to the rapid phase of NMDA receptor expression during this period, ${ }^{216}$ the number of binding sites would be substantially greater on PND 7 compared with PND 6 as reflected in the present results. $\left[{ }^{3} \mathrm{H}\right] \mathrm{TCP}$ binding was reduced by $83 \%$ in 2-h MK-801-pretreated PND 7 animals compared with saline-treated controls (MK-801treated, $n=3,26.2 \pm 4.9$ vs saline-treated, $n=3$, $161.3 \pm 54.9 \mathrm{fmol} / \mathrm{mg}$ protein, $P<0.01$, paired $t$ test). In contrast quisqualate-sensitive $\left[{ }^{3} \mathrm{H}\right]$ glutamate binding to high affinity receptors was not affected by $2 \mathrm{~h}$ MK-801 pretreatment (MK-801-treated, $n=3, \quad 781.9 \pm 12.9 \quad$ vs saline-treated, $n=3$, $868.6 \pm 36.9 \mathrm{fmol} / \mathrm{mg}$ protein).

In rats that received MK-801 $24 \mathrm{~h}$ prior to being killed, NMDA-sensitive [ $\left[{ }^{3} \mathrm{H}\right]$ glutamate binding remained elevated (Figs 5 and 6). Autoradiographic 

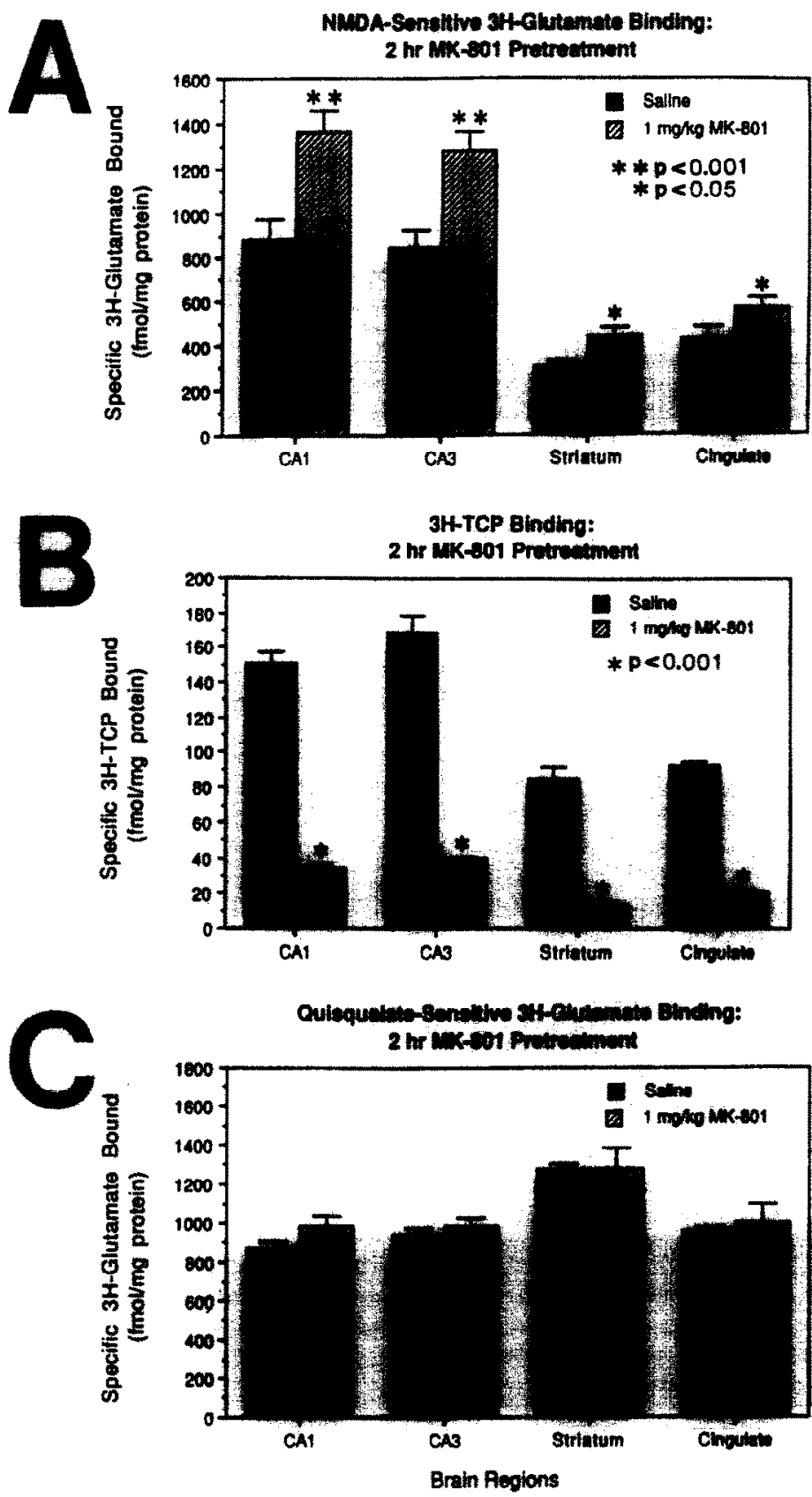

Fig. 4. Histograms comparing receptor binding in PND 7 rats that received either $1 \mathrm{mg} / \mathrm{kg}$ MK-801 or saline, i.p., $2 \mathrm{~h}$ prior to being killed. All three binding studies were carried out using adjacent sections from the same brains of three MK-801-treated and three saline-treated animals. (A) NMDA-sensitive glutamate binding was measured with $40 \mathrm{nM}$ [ ${ }^{3}$ H]glutamate in $50 \mathrm{mM}$ Tris-acetate, $\mathrm{pH} 7.2$, plus $2.5 \mu \mathrm{M}$ quisqualate. Non-specific binding was determined in the presence of $1 \mathrm{mM}$ glutamate. (B) ${ }^{3} \mathrm{HTTCP}$ binding was carried out in $50 \mathrm{mM}$ Tris-acetate, pH 7.4, containing $30 \mathrm{nM}$ [ ${ }^{3} \mathrm{H}$ TrCP plus $1 \mathrm{mM}$ magnesium acetate. Nonspecific binding was determined in the presence of $20 \mu \mathrm{M}$ TCP. (C) Ouisqualate-sensitive dutamate binding was measured with $40 \mathrm{nM}$ ['H]glutamate in $50 \mathrm{mM}$ Tris-HCl, $\mathrm{pH} 7.4$, plus $100 \mu \mathrm{M} \mathrm{NMDA}$ and $2.5 \mathrm{mM} \mathrm{CaCl}$. One millimolar glutamate was used to determine non-specific binding. See Experimental Procedures for details of autoradiography protocols. 8.9 .14 Values in $A, B$ and $C$ represent mean \pm S.E.M. and were quantitated in four brain regions: $\mathrm{CAl}$ and $\mathrm{CA} 3$ hippocampal subfields (stratum radiatum), corpus striatum, and cingulate cortex. Statistical comparisons were made using one-way ANOVA.

assays of NMDA-sensitive [ ${ }^{3} \mathrm{H}$ ]glutamate binding indicated that binding was increased by $29-50 \%$ in MK-80I-treated animals in all four brain regions examined: CA1 and CA3 hippocampal subfields
( $29 \%$ increase), corpus striatum ( $51 \%$ ), and cingulate cortex $(38 \%) \quad[P<0.05$, MK-801-treated $(n=3)$ vs saline-treated $(n=3)$, ANOVA]. In contrast, $\left[{ }^{3} \mathrm{H}\right] \mathrm{TCP}$ binding was reduced in rats treated with 


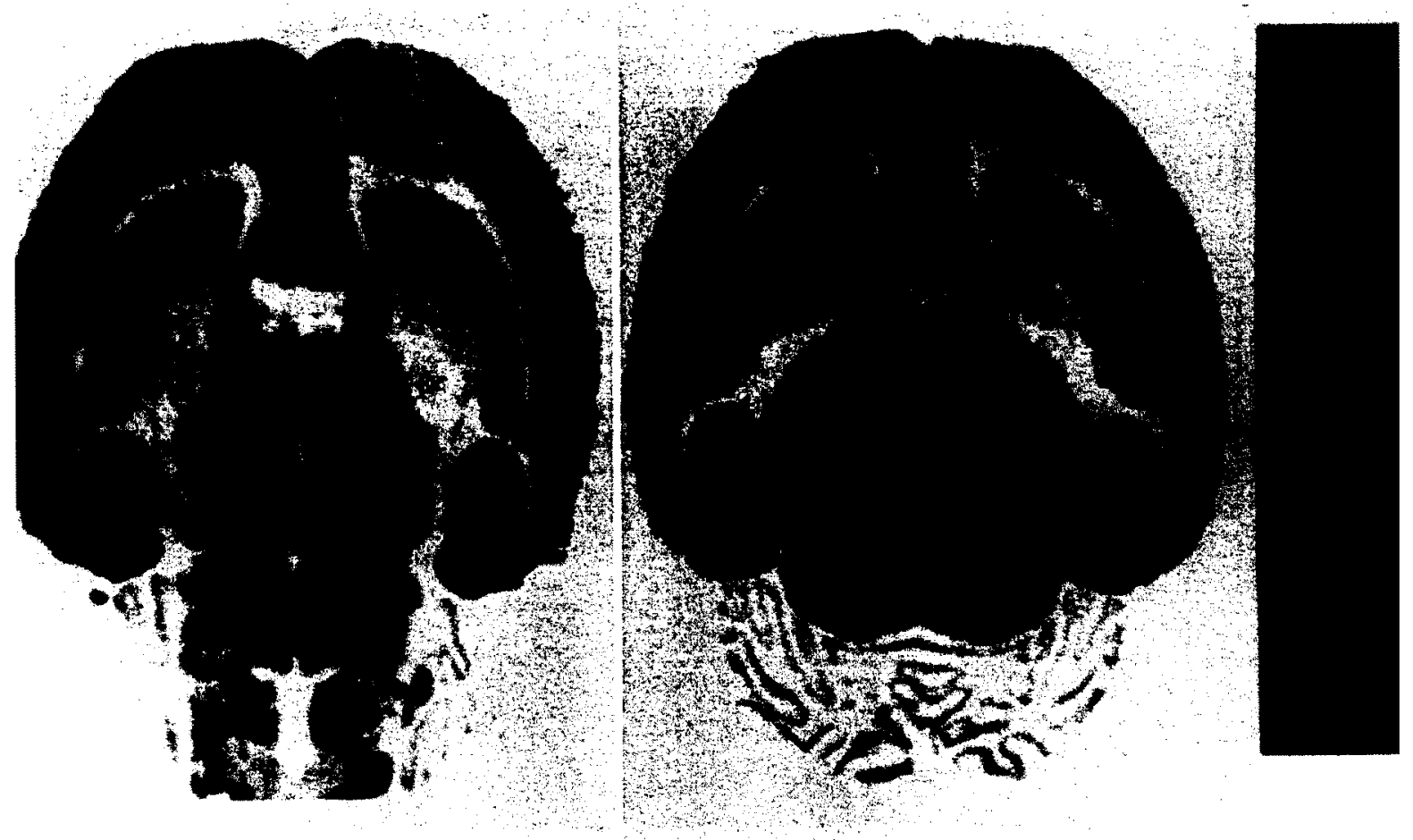

Fig. 5. Representative autoradiograms of NMDA-sensitive [ $\left.{ }^{3} \mathrm{H}\right]$ glutamate binding in seven-day-old rats that received either saline (A) or $1 \mathrm{mg} / \mathrm{kg}$ MK-801 (B) $24 \mathrm{~h}$ earlier. Highest densities of binding are represented by dark regions on the autoradiograms. See Experimental Procedures for details of the autoradiographic assays.

$1 \mathrm{mg} / \mathrm{kg}$ MK-801 $24 \mathrm{~h}$ before they were killed (Fig. 6). Binding was reduced by $40 \%$ in CAl and CA3 hippocampal subfields with a similar trend in the striatum and cingulate $[P<0.05, M K-801$ treated $(n=3)$ vs saline-treated $(n=3)$, ANOVA]. Quisqualate-sensitive glutamate binding was reduced in MK-801-treated animals (Fig. 6). Binding in the CA3 hippocampal subfield and in the corpus striatum was reduced by approximately 15 and $20 \%$, respectively $[P<0.05$ for each area, MK-80]-treated $(n=3)$ vs saline-treated ( $n=3$ ), ANOVA]. Binding did not differ significantly between groups in area $\mathrm{CAl}$ and cingulate.

\section{DISCUSSION}

Our results demonstrate that, in addition to the well described neuroprotective effects of MK$801,{ }^{5.6 .16 .17 .20}$ treatment with MK-801 may also sensitize the brain to NMDA receptor-mediated brain injury as levels of the drug decline in the brain. In contrast to the neuroprotective effects of $1 \mathrm{mg} / \mathrm{kg}$ of MK-801 when administered $0.5-12 \mathrm{~h}$ before intrastriatal injection of $25 \mathrm{nmol}$ NMDA, extension of this interval to $24 \mathrm{~h}$ results in a paradoxical increase in the severity of NMDA-mediated brain injury in compari- son with saline-treated, NMDA-injected controls. One possible explanation for the enhanced toxicity of NMDA after $24 \mathrm{~h}$ MK-801 pretreatment may be that MK-801 produces adverse metabolic effects related to sedation and reduced intake of milk. However, in rats that received two i.p. injections of chloral hydrate, at doses that resulted in a similar depth and duration of sedation as produced by MK-801, the severity of NMDA-induced brain injury did not differ from that produced in saline-treated controls. Thus it is unlikely that decreased food intake or other adverse systemic effects produced by sedation directly contributed to the increased severity of injury. The reported neurotoxic properties of MK-801 when administered in vivo are unlikely related to enhanced toxicity of NMDA in animals pretreated for $24 \mathrm{~h}$ with MK-801, since the reported pathological changes associated with MK801 treatment are: small relative to the increased severity of NMDA toxicity, acute, reversible and regionally restricted. ${ }^{252}$ Also, no histologic signs of neurotoxicity were observed in animals treated with MK-801 alone when assessed six days later. Furthermore, the effect of MK-801 pretreatment was selective for enhancement of NMDA-mediated brain injury since quisqualate-mediated brain injury was not increased by a similar MK-801 pretreatment. 

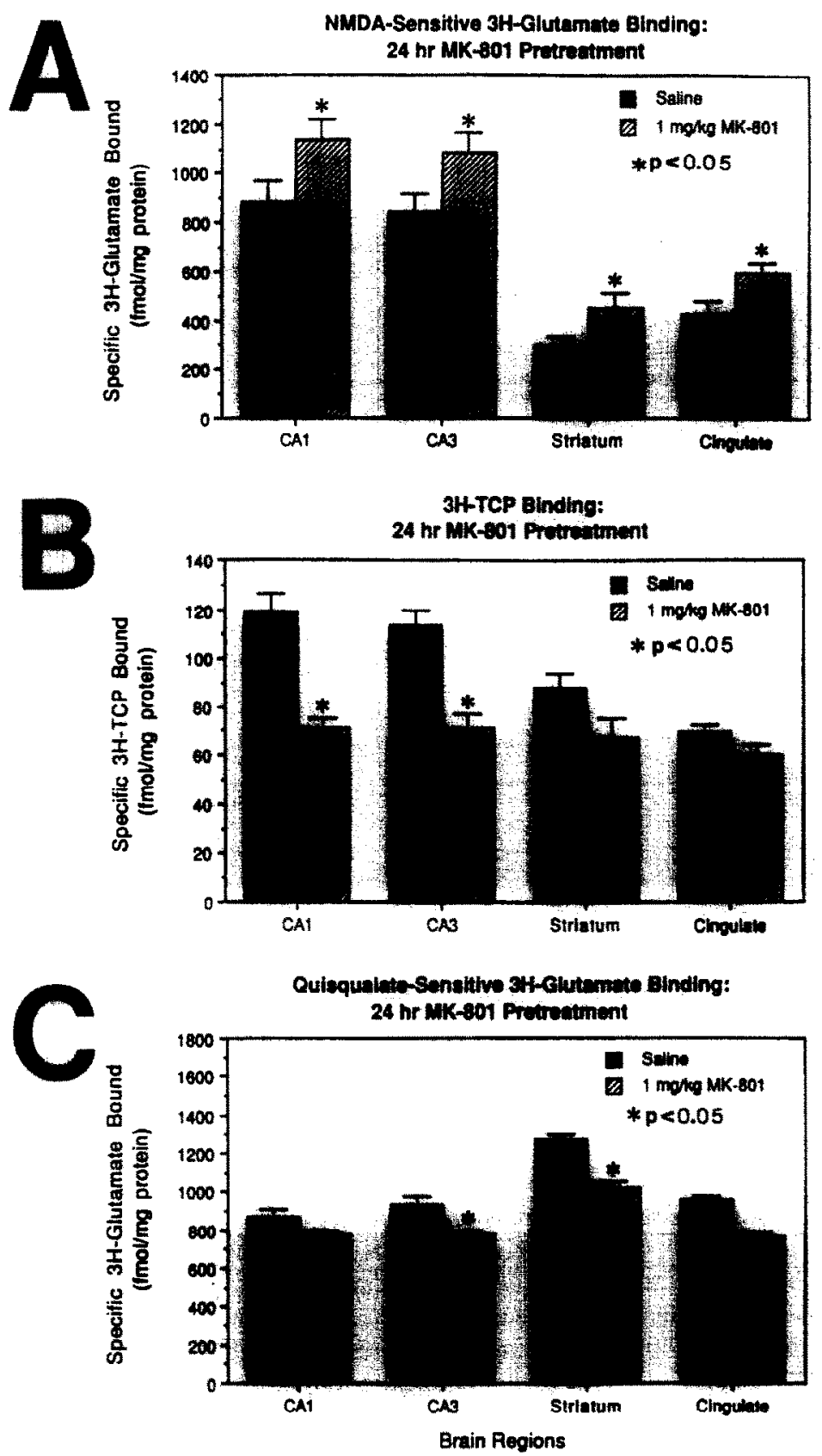

Fig. 6. Histograms comparing receptor binding in seven-day-old rats that received either $1 \mathrm{mg} / \mathbf{k g} \mathbf{M K}-801$ or saline, i.p., $24 \mathrm{~h}$ prior to being killed. All three binding studies were carried out using adjacent sections from the same brains of three MK-801-treated and three saline-treated animals. (A) NMDA-sensitive glutamate binding, (B) [ ${ }^{3} \mathrm{H}$ TrCP binding, (C) quisqualate-sensitive glutamate binding. Values in A, B and $C$ represent mean \pm S.E.M. and were quantitated in four brain regions: CAI and CA3 hippocampal subfields, corpus striatum, and cingulate cortex. Statistical comparisons were made using one-way ANOVA. See Fig. 4 legend for details of autoradiographic methods.

The enhanced toxicity of NMDA produced by MK-801 pretreatment was completely blocked by a second injection of MK-801 15 min after intrastriatal injection of NMDA. This observation suggested that the enhanced toxicity produced by MK-801 pretreatment is mediated by NMDA receptor-channel activation.
Treatment with MK-801 2 or $24 \mathrm{~h}$ prior to being killed, produced a marked increase in NMDA-sensitive $\left[{ }^{3} \mathrm{H}\right] \mathrm{g}$ lutamate binding. Scatehard analysis of the data indicated that the increase in binding produced by $2 \mathrm{~h}$ MK-801 pretreatment reflected mainly an increase in the number of receptors. Although Scatchard analysis of binding at $24 \mathrm{~h}$ was not 
examined, the data presented here suggest that the up-regulation of NMDA recognition sites persists up to $24 \mathrm{~h}$.

Two hours after MK-801 administration, the levels of MK-801 in the brain are apparently sufficient to block NMDA neurotoxicity despite receptor regulation. The heightened sensitivity of the brain to NMDA neurotoxicity found $24 \mathrm{~h}$ after MK-801 administration may be related to the persistent increased number of NMDA recognition sites after the level of MK-801 in the brain and its neuroprotective effects have diminished. Our observation that a second injection of MK-801 shortly after the intrastriatal injection of NMDA completely blocks the enhanced toxicity is consistent with this hypothesis.

Although MK-801 reduces quisqualate-mediated brain damage when administered concurrently, ${ }^{21}$ quisqualate toxicity is unaltered by $24 \mathrm{~h} \mathrm{MK}-801$ pretreatment. Thus, the mechanism underlying enhanced NMDA toxicity appears to be specific rather than a non-selective effect on neuronal metabolism.

The mechanisms by which MK-801 treatment alters NMDA-sensitive [ $\left.{ }^{3} \mathrm{H}\right]$ glutamate and $\left[{ }^{3} \mathrm{H}\right]$ TCP binding to NMDA receptor-channels and quisqualate-sensitive $\left[{ }^{3} \mathrm{H}\right]$ glutamate binding in the perinatal rat brain remain uncertain. The NMDA recognition site is closely linked to the binding site for [ $\left.{ }^{3} \mathrm{H}\right] \mathrm{TCP}$ within the NMDA operated ionophore (PCP receptor); $\left[{ }^{3} \mathrm{H}\right] \mathrm{TCP}$ and $\left[{ }^{3} \mathrm{H}\right] \mathrm{MK}-801$ binding are enhanced in the presence of NMDA receptor agonists and are reduced by NMDA receptor antagonists. 12.27 .34 The increase in NMDA-sensitive [ $\left.{ }^{3} \mathrm{H}\right]$ glutamate binding produced by MK-801 may reflect a compensatory response to transient channel blockade. Of note, in other experimental paradigms attempts to up-regulate the NMDA recognition site by denervation have been unsuccessful. ${ }^{15}$

The marked decrease in [ $\left.{ }^{3} \mathrm{H}\right] \mathrm{TCP}$ binding following $2 \mathrm{~h}$ MK- 801 pretreatment presumably reflects PCP receptor occupation by MK-801 since $2 \mathrm{~h}$ MK-801 pretreatment completely blocks NMDA toxicity. However, the decrease in [ $\left.{ }^{3} \mathrm{H}\right] \mathrm{TCP}$ binding produced by $24 \mathrm{~h}$ MK-801 pretreatment has at least two afternative interpretations: (1) occupation of the ionophore binding site by MK-801; (2) regulation of the affinity or number of binding sites. Our data cannot directly test these two possibilities. The concentration of MK-801 in the brain of PND 7 rats administered $1 \mathrm{mg} / \mathrm{kg} \mathrm{MK-801} 24 \mathrm{~h}$ earlier is not known. Yet if MK-801 levels remained high at $24 \mathrm{~h}$, neuroprotection rather than the observed enhanced NMDA-mediated brain injury would be expected. $\left[{ }^{3} \mathrm{H}\right] \mathrm{TCP}$ binding is dependent on the state of activation of the NMDA receptor associated ion channel. ${ }^{12.27 .34}$ Thus, the decrease in $\left[{ }^{3} \mathrm{H}\right] \mathrm{TCP}$ binding may also reflect altered coupling (i.e. affinity change) to the modulatory sites on the NMDA receptor complex or receptor down-regulation. Detailed phar* macological studies and temporal measurements of brain MK-801 content will be required to delineate the mechanism by which $24 \mathrm{~h}$ MK-801 pretreatment reduces [ $\left.{ }^{3} \mathrm{H}\right] \mathrm{TCP}$ binding. Although these mechanistic details remain unknown, the major conclusion that $24 \mathrm{~h}$ MK-801 pretreatment enhances both NMDA receptor binding and NMDA toxicity remains intriguing.

The susceptibility of the brain to NMDA toxicity changes during development. Our study focused on NMDA-induced neurotoxicity in PND 7 rats because NMDA-induced neurotoxicity peaks on this day ${ }^{18}$ and the excitotoxic lesion is well characterized at this age ${ }^{20-21 a}$ Compared with adult rats, on PND 7 direct intracerebral injection of NMDA produces a more extensive lesion that is about 60 times larger per dose. Neurophysiologic studies have also shown that NMDA receptors in developing brain are more effective than in adult brain. Whether the actions of MK-801 pretreatment on NMDA receptor binding and NMDA toxicity are a general phenomena or restricted to a specific developmental period requires additional studies at other developmental time points. However, the ability of PCP-like compounds to increase NMDA-sensitive [ ${ }^{3} \mathrm{H}$ ]glutamate binding does not appear to be limited to the developing brain. The dissociative anesthetic ketamine (which acts at the PCP receptor) can also produce a rapid increase in NMDA-sensitive glutamate binding in adult rat brain when administered $(100 \mathrm{mg} / \mathrm{kg}$, i.p.) $30 \mathrm{~min}$ prior to being killed (Young and Greenamyre, personal communication). Whether MK-801 can also enhance the toxicity of MK-801 in the adult brain has not been examined.

The results provide novel information about NMDA receptor-channel regulation and relate these changes to alterations in the pathophysiology of NMDA toxicity. They provide the first evidence that a non-competitive NMDA antagonist, MK-801, induces a rapid, persistant and selective increase in NMDA-sensitive $\left[{ }^{3} \mathrm{H}\right]$ glutamate binding and selectively sensitizes the brain to NMDA-mediated brain injury as the neuroprotective effect of the drug declines. The NMDA receptor-channel may participate in a wide range of neurophysiologic and pathophysiologic processes in both the developing and adult nervous system. Acute administration of MK-801and PCP-like compounds protects the brain from a variety of insults including physical trauma, hypoxiaischemia, and sustained seizures associated with NMDA receptor overactivation ${ }^{6.16,22.30}$ and these compounds (e.g. MK-801) may have considerable neuroprotective properties in a variety of neurologic disorders. ${ }^{1.7,13.23 .28 .37}$ However, our results suggest that these compounds may also sensitize the brain to excitotoxic injury.

The pharmacology of MK-801 and PCP-like compounds in vivo appears to be complex. In addition to blocking NMDA responses and NMDA-mediated brain injury, they also regulate NMDA recognition 
site binding in a complex manner. Antagonists of NMDA receptors may provide a unique therapeutic approach in many neurologic disorders. These observations suggest that considerably more information is needed about the effects of these ligands in vivo in order to anticipate potential limitations in their use.
Acknowledgements-Supported by USPHS grants IP0INS19613 (M.V.J.) 1K08NS0117 (F.S.S.) MSTP grant 5 T32 6M07863-07 (J.W.M.). K. Gordon MD. MS was a statistical consultant. We thank S. M. Scholler, H. M. Arft and K. T. O'Mara for technical assistance. MK-80I was a gift of Dr P. Anderson, Merck, Sharp and Dohme, West Point, PA.

\section{REFERENCES}

1. Beal M. F., Kowall N. W., Ellison D. W., Maxurek M. F., Swartz K. J. and Martin J. B. (1986) Replication of the neurochemical characteristics of Huntington's disease by quinolinic acid. Nature 321, 168-172.

2. Clia J. J., Greenamyre J. T., Nielsen E. O., Penney J. B. and Young A. B. (1988) Properties of quisqualate sensitive $\mathrm{L}-\left[{ }^{3} \mathrm{H}\right] \mathrm{glutamate}$ binding sites in rat brain as determined by quantitative autoradiography. $J$. Neurochem. 51, $469-478$.

3. Collins R. C. and Olney J. W. (1982) Focal cortical seizures cause distant thalamic lesions. Science 218, 177-179.

4. Foster A. C., Collins J. F. and Schwarcz R. (1983) On the excitotoxic properties of quinolinic acid, 2-3-piperidine dicarboxylic acids and structurally related compounds. Neuropharmacology 22, 1331-1342.

5. Foster A. C., Gill R., Kemp J. A. and Woodruff G. N. (1987) Systemic administration of MK-801 prevents $N$-methyl-D-aspartate induced neuronal degeneration in rat brain. Neurosci. Lett. 76, 307-311.

6. Gill R., Foster A. C. and Woodruff G. N. (1987) Systemic administration of MK-801 protects against ischemia-induced hippocampal neurodegeneration in the gerbil. J. Neurosci. 7, 3343-3349.

7. Greenamyre J. T. (1986) The role of glutamate in neurotransmission and in neurologic disease. Archs Neurol. 43, $1058-1063$.

8. Greenamyre J. T., Young A. B. and Penney J. B. (1984) Quantitative autoradiographic distribution of L- ${ }^{3} \mathrm{H}$-glutamate binding sites in rat central nervous system. $J$. Neurosci. 4, 2133-2144.

9. Greenamyre J. T., Olson J. M. M., Penney J. B. and Young A. B. (1985) Autoradiographic characterization of $N$-methyl-D-aspartate, quisqualate- and kainate-sensitive glutamate binding sites. $J$. Pharmac. exp. Ther. 233, $254-263$.

10. Hasting M. H., Winn P. and Dunnett S. B. (1985) Neurotoxic amino acid lesions of the lateral hypothalamus: a parametric comparison of the effects of ibotenate, $N$-methyl-D-L-aspartate and quisqualate in the rat. Brain Res. 360, $248-256$.

11. Kemp J. A., Foster A. C. and Wong E. H. F. (1987) Non-competitive antagonists of excitatory amino acid receptors Trends Neurosci. 10, 294-299.

12. Loo P., Braunwalder A., Lehmann J. and Williams M. (1986) Radioligand binding to central phencyclidine recognition sites is dependent on excitatory amino acid receptor agonists. J. Pharmac. 123, 467-468.

13. Maragos W. F., Greenamyre J. T., Penney J. B. and Young A. B. (1987) Glutamate dysfunction in Alzheimer's disease: an hypothesis. Trends Neurosci. 10, 65-68.

14. Maragos W. F., Penney J. B. and Young A. B. (1988) Anatomic correlation of NMDA and ${ }^{3}$ H-TCP-labeled receptors in rat brain. $J$. Neurosci. 8, 493-501.

15. Maragos W. F. (1987) [ $\left.{ }^{3} \mathrm{H}\right] \mathrm{TCP}$ as a potential anatomical marker for $N$-methyl-D-aspartate receptors. Doctoral Thesis, University of Michigan, pp. 66-101.

16. McDonald J. W., Silverstein F. S. and Johnston M. V. (1987) MK-801 protects the neonatal brain from hypoxicischemic damage. Eur. J. Pharmac. 140, 359-361.

17. McDonald J. W., Silverstein F. S., Cardona D., Uckele J., Chen R. and Johnston M. V. (1988) Neuroprotective effects of MK-801 and other compounds on perinatal hypoxic-ischemic injury. In Sigma and PCP like compounds and molecular Probes in Biology (eds Domino E. F. and Kamenka J.-M.), pp. 697-707.

18. McDonald J. W., Silverstein F. S. and Johnston M. V. (1988) Neurotoxicity of $N$-methyl-D-aspartate is markedly enhanced in developing rat central nervous system. Brain Res. 459, 200-203.

19. McDonald J. W., Silverstein F. S. and Johnston M. V. (1988) MK-801 pretreatment enhances NMDA mediated brain injury and alters NMDA receptor and PCP receptor binding characteristics in perinatal rats. Soc. Neurosci. Abstr. 14, 746.

20. McDonald J. W., Silverstein F. S. and Johnston M. V. (1989) Neuroprotective effects of MK-801, TCP. PCP and CPP against $N$-methyl-D-aspartate induced neurotoxicity in an in vivo perinatal rat model. Brain Res. 490, 33-40.

21. McDonald J. W., Silverstein F. S., Cardona D., Hudson C., Chen R. and Johnston M. V. (1990) Systemic administration of $\mathrm{MK}-801$ protects against $N$-methyl-D-aspartate and quisqualate mediated neurotoxicity in perinatal rats. Neuroscience 36, 589-599.

21a. McDonald J. W., Roeser N. F., Silverstein F. S. and Johnston M. V. (1989) Quantitative assessment of neuroprotection against NMDA-mediated brain injury. Expl Neurol. 106, 289-296.

21b. McDonald J. W. and Johnston M. V. (1990) Physiological and pathophysiological roles of excitatory amino acids during central nervous system development. Brain Res. 15, 41-70.

22. McIntosh T., Soares H., Hayes R. and Simon R. (1988) The NMDA receptor antagonist MK-801 prevents edema and restores magnesium homeostasis after traumatic brain injury in rats. In Frontiers in Excitatory Amino Acid Research (eds Cavalheiro E. A., Lehmann J. and Turski L.), Vol. 46, pp. 653-656. Alan R. Liss, New York.

23. Meldrum B. (1985) Possible therapeutic implications of antagonists of excitatory amino acid neurotransmitters. Clin. Sci. 68, $113-122$.

24. Monaghan D. T., Holets V. R., Toy D. W. and Cotman C. W. (1983) Anatomical distributions of four pharmacologically distinct ${ }^{3} \mathrm{H}-\mathrm{L}$-glutamate binding sites. Nature 306, 176-179.

25. Nadler J. V., Perry B. W. and Cotman C. W. (1978) Intraventricular kainic acid preferentially destroys hippocampal pyramidal cells. Nature 271, $676-677$

25a. Olney J. W., Labruyere J. and Price M. T. (1989) Pathological changes induced in cerebrocortical neurons by phencyclidine and related drugs. Science 244, 1360-1362.

26. Pan H. S., Frey K. A., Young A. B. and Penney J. B. (1983) Changes in [ $\left.{ }^{3} \mathrm{H}\right]$ muscimol binding in substantia nigra. entopeduncular nucleus, globus pallidus and thalamus after striatal lesions as demonstrated by quantitative autoradiography. J. Neurosci. 3, 1189-1198. 
27. Reynolds I. J., Murphy S. N. and Miller R. J. (1987) ${ }^{3}$ H-labeled MK-801 binding to the excitatory amino acid receptor complex from rat brain is enhanced by glycine. Proc. natn. Acad. Sci. U.S.A. 84, 7744-7748.

28. Robinson M. B. and Coyle J. T. (1987) Glutamate and related acidic excitatory neurotransmitters from basic science to clinical application. Fedn Am. Soc. exp. Biol. J. 1, 446-455.

29. Rothman S. (1984) Synaptic release of excitatory amino acid neurotransmitter mediates anoxic neuronal death. J. Neurosci. 4, 1884-1891.

30. Rothman S. M. and Olney J. W. (1987) Excitotoxicity and the NMDA receptor. Trends Neurosci. 10, 299-302.

31. Silverstein F. S., Chen R. C. and Johnston M. V. (1986) The glutamate agonist quisqualic acid is neurotoxic in striatum and hippocampus of immature rat brain. Neurosci. Lett. 71, 13-18.

32. Simon R. P., Swan J. H., Giffiths T. and Meldrum B. S. (1984) Blockade of $N$-methyl-D-aspartate receptors may protect against ischemic damage in the brain. Science 226, 850-852.

33. Sloviter R. S. (1983) "Epileptic" brain damage in rats induced by sustained electrical stimulation of the perforant path. I. Acute electrophysiological and light microscopic studies. Brain Res. Bull. 10, 675-697.

34. Snell L. D., Morter R. S. and Johnson K. M. (1987) Glycine potentiates $N$-methyl-D-aspartate-induced $\left[{ }^{3} H\right]$ TCP binding to rat cortical membranes. Neurosci. Lett. 83, 313-317.

35. Stewart G. R., Price M., Olney J., Harmant B. K. and Cozzari C. (1986) N-Methylaspartate: an effective tool for lesioning basal forebrain cholinergic neurons of the rat. Brain Res. 369, 377-382.

36. Wieloch T. (1985) Hypoglycemia-induced neuronal damage prevented by an $N$-methyl-D-aspartate antagonist. Science 230, 681-683

37. Young A. B., Greenamyre J. T., Hollingsworth Z., Albin R., D’Amato C., Shoulson I. and Penney J. B. (1988) NMDA receptor losses in putamen from patients with Huntington's disease. Science 241, 981-983. 